\title{
Applying Strategic Niche Management to understand how universities contribute to the development of social innovation niches: the case of the Social Innovation Scientific Park in Colombia
}

\author{
Aplicación de la Gestión Estratégica de Nichos \\ para comprender cómo las universidades contibuyen \\ al desarrollo de los nichos de innovación social: el caso \\ del Parque Científico de Innovación Social en Colombia
}

SARA CALVO, ANDRÉS MORALES \& JEFFERSON ENRIQUE ARIAS GÓMEZ

Middlesex University London - The Open University \& Corporacion Universitaria Minuto de Dios

Artículo recibido: 31 de enero de 2018

Solicitud de revisión: 3 de abril de 2018

Artículo aceptado: 3 de septiembre de 2018

Calvo, Sara; Morales, Andrés \& Arias Gómez, Jefferson Enrique (2018). Applying Strategic

Niche Management to understand how universities contribute to the development of social innovation niches: the case of the Social Innovation Scientific park in Colombia. Revista de Pensament $i$ Analisi, 23, pp. 95-130.

\begin{abstract}
Little literature has looked at the role of universities promoting and supporting grassroots social innovations. This paper addresses this gap by examining how universities contribute to social innovation in Colombia. In seeking to develop a good understanding of how universities can contribute to the development of social innovation niches, we draw upon the Strategic Niche Management theory and the three areas of activity which constitute effective niche-building: social networks, expectations and visions and learning. We explore this phenomenon with the Parque Científico de Innovación Social, founded by Uniminuto University in 2012, using video case study research methodology. Findings suggest the important role played by Uniminuto University influencing the current higher education system regime by enhancing the development of social innovation niches. These results have implications for advancing the debate on the role of higher education institutions in contributing to the development of social innovation processes.
\end{abstract}

Key words: Social Innovation; Strategic Niche Management; higher education; Colombia 


\section{Resumen}

Poca literatura ha analizado el papel de las universidades promoviendo y apoyando las innovaciones sociales de base. Este documento aborda esta brecha al examinar cómo las universidades contribuyen a la innovación social en Colombia. Al tratar de desarrollar una buena comprensión de cómo las universidades pueden contribuir al desarrollo de nichos de innovación social, recurrimos a la teoría de Gestión Estratégica de Nichos y las tres áreas de actividad que constituyen la creación efectiva de nichos: redes sociales, expectativas y visiones y aprendizaje. Exploramos este fenómeno con el Parque Científico de Innovación Social, fundado por la Universidad de Uniminuto en 2012, utilizando la metodología de investigación de estudios de casos de video. Los hallazgos sugieren el importante papel desempeñado por la Universidad de Uniminuto que influye en el régimen actual del sistema de educación superior al mejorar el desarrollo de nichos de innovación social. Estos resultados tienen implicaciones para avanzar en el debate sobre el papel de las instituciones de educación superior en la contribución al desarrollo de los procesos de innovación social.

Palabras clave: Innovación social; Gestión Estratégica de Nichos; educación superior; Colombia

\section{INTRODUCTION}

The term 'social innovation' (SI) has gained momentum over the last decade, and it is very popular among policy makers, academics and practitioners (Cajaiba-Santana, 2014). SI can be defined as a novel activity or organisational mode that is not, or at least not primarily, motivated by earning profits for individuals but is primarily intended to address complex societal challenges (Pol and Ville, 2009; McKelvey and Zaring, 2017).

The current higher education (HE) system regime focused on the demands of the market, leading universities to become competitive institutions and collaborate primarily with big private corporations and the public sector rather than grassroots organisations and vulnerable populations (Benson et al., 2007; Checkoway, 2001; Deiaco et al., 2012). One major debate about the role of higher education institutions (HEIs) is the extent to which they can contribute to business innovation and economic development. A study by Salter and Martin (2001) identified six major mechanisms by which HEIs can help: increasing the stock of useful knowledge, educating skilled graduates, developing new scientific instrumentation/ methodologies, shaping networks and stimulating social interaction, enhancing the capacity for scientific and technological problem-solving and creating new firms. Yet, little literature has looked at the role of universities contributing to the development of grassroots social innovations (Perkmann et al., 2013; Benneworth and Cunha, 2015; British Council, 2016; McKelvey and Zaring, 2017). 
In seeking to develop a good understanding of how HEIs can contribute to the development of SI, this paper draws upon the Strategic Niche Management (SNM) theory and applies this within the Colombian context (Schot and Geels, 2014). While most research within SNM to date has focused on managed technological innovation in market contexts, a body of work on 'social innovations' that examines grassroots civil society-led initiatives for sustainability is growing (Seyfang and Smith, 2007; Seyfang et al., 2014). Hence, this paper contributes to our knowledge of the phenomenon of SNM by testing the applicability of this theory to the context of HEIs (considered this to be part of grassroots social innovations), as well as to advancing the debate on the role of universities in contributing to the development of SI niches and influencing the current HE system regime.

The field of SI in the context of HEIs will be explored by selecting the Social Innovation Scientific Park (in Spanish, Parque Científico de Innovación Social or PCIS), located within Uniminuto University to promote and support social innovation, as a case study. Since its establishment, Uniminuto University has developed a range of SI related programmes, aimed at addressing inequalities and social exclusion by supporting staff and students from vulnerable and low-income backgrounds to make a positive contribution to the communities in which they live, work and study (Arias, 2013b).

This paper raises a series of questions: Can we explain how do universities contribute to the development of SI niches using SNM? To what extent do the experiences of PCIS at Uniminuto University and their interactions with networks and intermediaries suggest that a 'niche management' is emerging, and at what stage of development is it? What are the challenges for promoting and supporting the development of a SI niche within the current Colombian HE system regime? The paper proposes a conceptual framework to help us understand this phenomenon. This framework is based on the literature overview in Section 2. Section 3 presents the case study and discusses the research methodology designed to illustrate the conceptual framework. Section 4 presents the research findings and discussion. The final section presents the conclusions of this paper and makes suggestions for further research. 


\section{LITERATURE REVIEW}

\subsection{Strategic Niche Management theory}

There is a growing interest in the governance of sociotechnical transitions in the context of debates about how modern industrial societies can attempt to shift towards more sustainable development (Grin et al, 2010). In recent years, a literature on sustainability transitions in the specific field of organisation and business management has emerged which posits a multilevel perspective (MLP) to capture the dialectical relationship between micro level actors and macro level structures (landscapes, regimes and niches) (Geels, 2002).

The transitions literature develops the notion of sociotechnical niches where a niche can emerge against a dominant sociotechnical regime. While regime is understood as a relatively stable and aligned set of rules directing the behaviour of a set of actors along the trajectory of incremental innovation, niches are conceived as protected spaces where novel sociotechnical configurations are established (often as a direct response to an unsustainable regime), experimented with, and developed, away from the normal selection pressures of the regime (Smith and Raven, 2012). Moreover, a landscape can be defined as exogenous events and trends that shape niche-regime dynamics. Seyfang and Smith (2007) distinguished two types of niche innovations: market based and grassroots. They argued that market based innovations differ from grassroots innovations in context (market vs social economy), driving force (profit vs social need), niche (market rules vs values), organisational form (firm vs diversity of organisations), and resources (commercial oriented vs diverse non-profit funding). For this paper, we are interested in exploring grassroots niche innovations.

The SNM approach has been developed to further understand and govern processes of niche creation (Schot and Geels, 2008). The SNM theory allows us to test the role of grassroots innovations (in this case, HEIs) as agents of change and their ability to form niche spaces where new ideas and practices can be developed (Raven, 2005; Geels, 2002). In the SNM literature, Schot and Geels (2008) identified three areas of activity which constitute effective niche-building looking at the conditions under which niches become influential: social networks, expectations and visions and learning. Firstly, a growing social network, including all relevant types of actors within the niche, both creates opportunities for stakeholder interaction and a micro market that provides the resources necessary for experi- 
mentation and temporary protection. Secondly, the articulation of expectations and visions of high quality by the participating actors, particularly when they are robust and shared by many actors, give direction and legitimacy to the niche (Witkamp et al., 2011). Third, and most important, are the learning processes at multiple dimensions. Learning processes should not be limited to first-order learning, that is, the gathering of facts and data, but should also comprehend second order learning, which is directed at changing cognitive frames and assumptions (Schot and Geels, 2008). SNM argues that the better these three processes and their interactions are managed, the greater the chance that the niche can develop into a market niche, transforming or becoming a viable alternative to an existing regime (Witkamp et al., 2011). As can be seen in Figure 1, there are four main phases in the development of shared technological knowledge: a local phase (a set of isolated projects), an inter-local phase (a niche level emerges where projects share knowledge and experiences), a trans-local phase (where actors play a role in developing interest to manage external expectations and local knowledge is systematically fed 'up' to constitute the aggregated learning required at niche level) and a global phase (where we see greater institutionalisation and standardisation of practices in the field with niche standards shaping local practices, therefore becoming a stable regime).

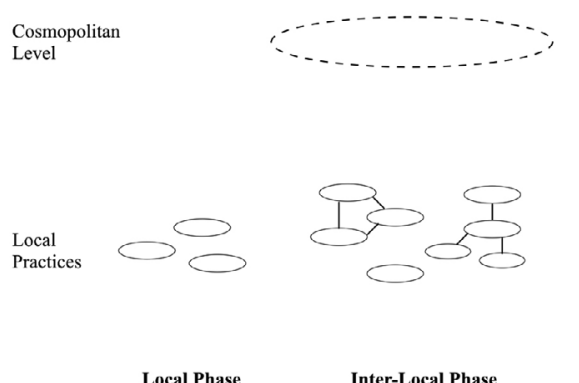

Local Phase

Inter-Local Phase

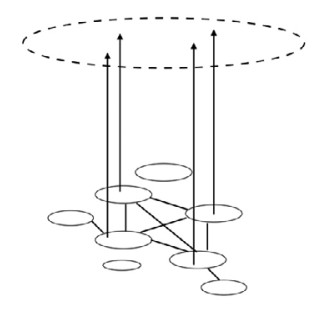

Trans-Local Phase

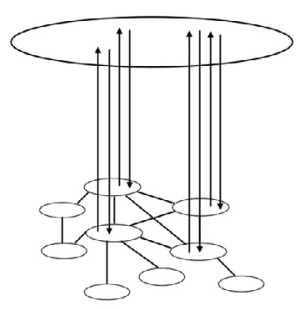

Global Phase

Source: Based in Geels and Deuten (2006: 269)

Figure 1

Phase in the development of shared technological knowledge 
As with other transition theories, SNM has not been without criticism. Some have criticised it for being too much of a bottom-up strategy focusing on single activities (Berkout et al, 2004). Moreover, others have commented that the SNM theory is vague as there are problems in explaining niche development as there is little evidence of initiatives becoming major learning vehicles for wider change towards new socio-technological regimes (Seyfang et al, 2014; Nill and Kemp, 2009). However, we consider that this paper can contribute to the existing SNM literature by generating useful insights into the stage of niche development and the challenges the SI niche face with the current Colombian HE system regime using the case study of the PCIS at Uniminuto university.

\subsection{Social Innovation in Higher Education: a new niche in Colombia?}

The concept of SI has become popular recently as an attempt to capture and describe bottom-up phenomena where new ideas, approaches, techniques and organisational forms grew from humble roots into substantive new social capacities (Benneworth and Cunha, 2015). Examples of SI are food co-ops, community supported forms of agriculture, social impact hubs and self-help portals among others. Three theoretical perspectives have guided the research on the subject of SI. In the first one, there is an 'agentic centered perspective', an individualistic and behaviorist approach, in which SI is created through the actions undertaken by specific individuals. The second approach is the 'structuralist perspective', in which SI is perceived as determined by the external structural context. The third approach is 'the structuration perspective', where SI is conceived as interactively influenced by both agents and social structures (Cajaiba-Santana, 2014).

Within the researched academic literature, three different understandings of SI can also be distinguished (Schmitt, 2014). The first strand focuses on non-technical innovations in an organisational context, where SI refers to improvements in social capital to enhance organisational effectiveness (Moulaert et al., 2007). The second strand regards SI as connected to technological innovation, reflecting the strong technology orientation of current innovation research (Howaldt \& Kopp, 2012). The third strand takes up the notion of SI as new social practices. The work of Zapf (1989: 177) can be considered the point of origin of this theoretical school defining social innovation as: 
new ways to reach aims, in particular new organizational forms, new regulations, new lifestyles, which alter the direction of social change and which solve problems better than former practices. They should be worth being imitated and institutionalised.

Most niche analysis to date has focused on market contexts and business-led technological innovations. In contrast, a growing body of work studying grassroots innovations frames radical community-based action for sustainability as an overlooked site of innovation for sustainability (Seyfang et al., 2014).

Previous research has examined SNM and SI in the context of complementary currencies (Seyfang and Longhurst, 2013b), energy (Hielscher et al., 2013), food (Hargreaves et al., 2013), and eco-housing (Avelino and Kunze, 2009). These studies have found that for participants, it is often the symbolic and shared practice of deep values which brings the principal benefits, rather than any tangible economic or material impacts. For example, local currency activists feel empowered by creating and using money which values people's labour equally; food activists highly value their ability to bypass supermarkets, even for relatively small proportions of their provisioning (Seyfang, 2009). These initiatives form 'pockets' of shared values different to mainstream norms, and communities of interest coalesce around them, in mutually supporting (hence, protective) spaces (Seyfang et al., 2014). However, these initiatives fail to scale up and become transferable as they are situated in local contexts and an absence of long-term resourcing and institutional support (Smith et al., 2013).

This work seeks to explore how HEIs can contribute to the development of SI niches, and seek insight into how the niche might be supported to overcome the challenges they face with the higher education (HE) system regime that focused on the demands of the market giving emphasis to private corporations and the public sector rather than grassroots organisations and vulnerable populations (Innerarity, 2010). We propose that SI initiatives have the following characteristics: a) the primary purpose of SI is social change rather than profit maximisation; b) SI results in improved welfare, quality of life or social relations; and c) SI is system-changing, altering perceptions, behaviours and structures and resulting in profound societal change (McKelvey and Zaring, 2017).

Whilst universities clearly have a role to play in creating new collective social systems, in the last 30 years, they have been modernised through individual processes including marketisation and privatisation, leaving them increasingly competitive rather than collaborative institutions (Benneworth and Cunha, 2013). Additionally, the marketisation in HE is demon- 
strated, as the modern reforms influencing the operation of universities and their programmes of study are presented as an element of their modernisation, according to the demands of the market (Middleton, 2000). Researchers have also dealt with the internationalisation of universities and the changes to the institutions in corresponding to the demands of a particular type of educational service for students, confronting them as customers-consumers (Stier \& Börjesson, 2010). A book published in 2009 by Boni and Walker about capabilities at universities argues that the human

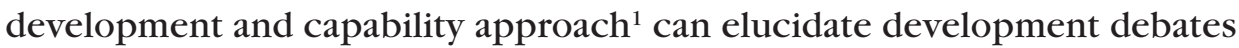
drawing on local, national and international issues, advocating for a new arena of engagement with universities as key sites of development and freedoms beyond human capital and challenging development omissions and gaps around university education.

A major debate concerns on the contributions of universities to innovation and employment. Several studies have been conducted about the impact of universities on the innovation industry (Feller et al 2002; Veugelers \& Del Rey, 2014). An example of this is the work conducted by Feller et al (2002) on how engineering research centers (ERC) sited in universities impact industrial innovation.Additionally, in the last years, there has also been interest in development thinking around universities and their contribution in making a more equal world.

We have recently observed a number of universities with a growing interest in supporting SI related projects in a variety of ways, for example, by providing placements and work opportunities for students in existing companies, university staff and researchers procuring or providing SI related services, or even students setting up their own initiatives (see Figure 2 for further details) (Calvo, 2015). While some universities have taken a 'top-down' approach by incorporating SI explicitly into their core strategic goals and embedding it across everything they do (for example, The Open University and Northampton University in the United Kingdom), others have provided tailored modules and support for students and graduates as part of a wider objective to support enterprise and enhance employability

1 «The human and capability approach is essentially a 'people-centered' approach, which puts human agency (rather than organizations such as markets or governments) at the centre of the stage. The crucial role of social opportunities is to expand the realm of human agency and freedom, both as an end in itself and as a means of further expansion of opportunity' (...) is a useful reminder not to view individuals and their opportunities in isolated terms. The options that a person has depend greatly on relations with others and on what the state and other institutions do. We shall be particularly concerned with those opportunities that are strongly influenced by social circumstances and public policy...» (Drèze \& Sen 2002: 6). 
(Calvo, 2015). These initiatives have been managed and/or supported by numerous student enterprise societies such as Student Hubs and incubators (for example, the Pontifical Catholic University of Chile).

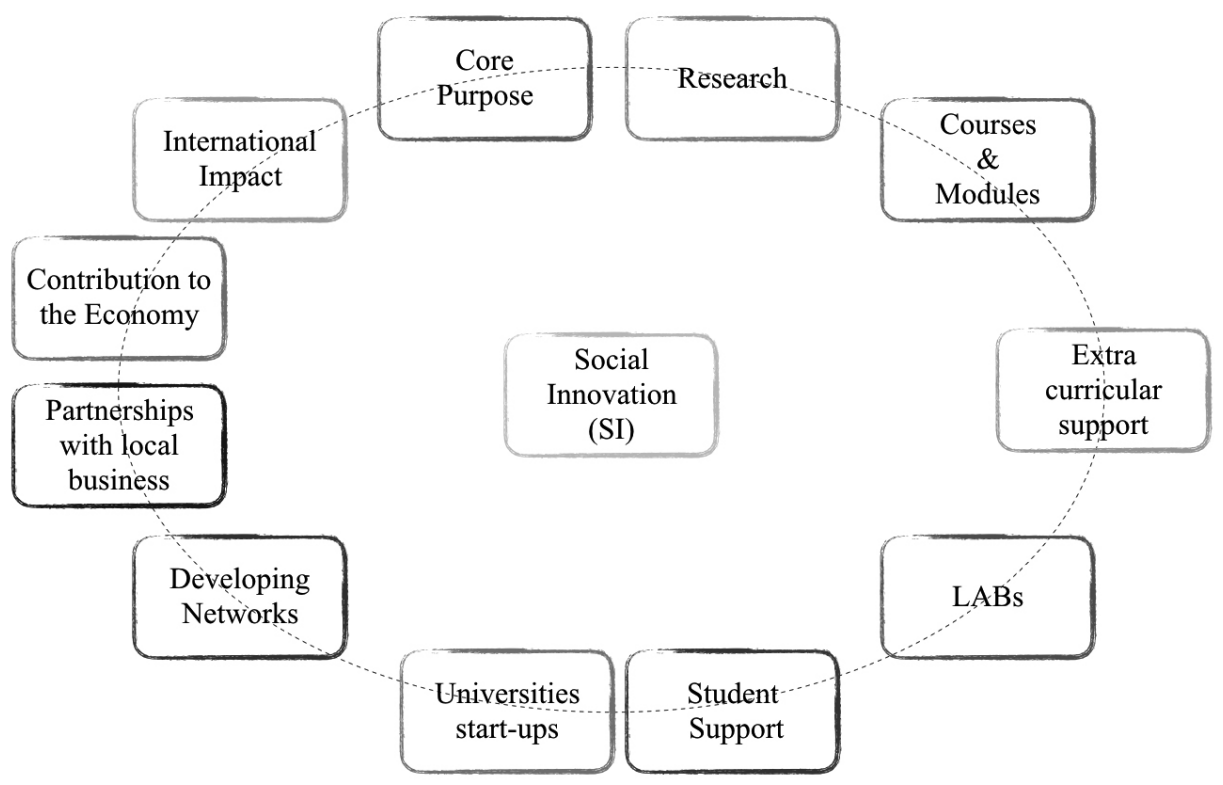

Source: Compiled by Authors

Figure 2

A typology of how universities can contribute to SI

Several studies have suggested that promoting and supporting SI in HEIs stimulate and sustain such practices, enhancing diversity, social inclusion, citizenship, and local learning communities and partnerships, which is central to economic growth and regeneration, and that it is therefore important to re-connect the social dimension of education with the economic (Matheson, 2008; British Council, 2016). For example, a recent book publication authored by Brundenius et al. (2017) shows the importance of inclusive development and innovation on economic growth and demonstrates the ways in which universities around the world are pioneers in 
this area through initiatives in social responsibility and social innovation. The research included in this book brings case studies from Latin America, Northern and Eastern Europe, and Sub-Saharan Africa, providing an insight into actions that are taken by universities on inclusive development and social innovation, and overall regional economic and social development.

To test the applicability of SNM in examining how universities contribute to the development of SI niches, we look for evidence of a SI niche being formed within the current HE system regime and explore this phenomenon with the PCIS at Uniminuto University.

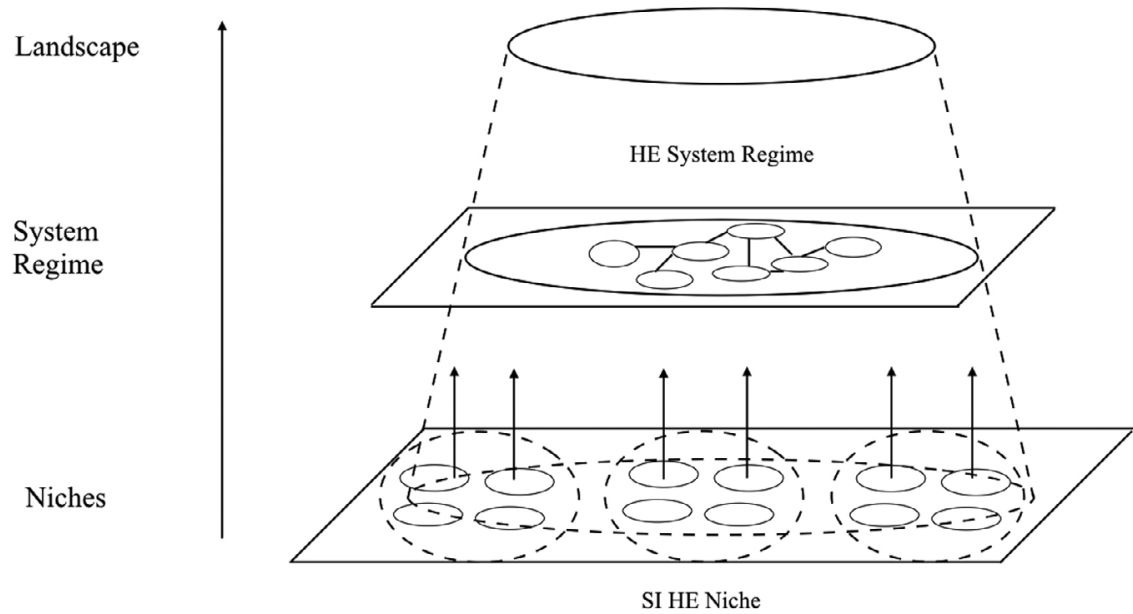

Source: Based in Geels and Deuten (2006: 269)

Figure 3

A multi-level perspective to explore SI in $\mathrm{HE}$ in Colombia

\section{METHODOLOGY}

The findings presented here are drawn from a qualitative case study research with the PCIS at Uniminuto University. As Yin (2009: 18) defines, a case study is 'an empirical inquiry that investigates a contemporary 
phenomenon in depth and within its real-life context, especially when the boundaries between the phenomenon and context are not clearly evident'. In this paper, we use video case study research as it permits us and the participants to express creatively and in doing so, enables the participants to express aspects of their experiences or emotions which would otherwise remain unsaid (Rakić \& Chambers, 2011). Besides this, video research allows us to present the findings in non-conventional ways, reaching wider audiences, empowering participants and making knowledge accessible and easier to share (Jewitt, 2012). Thus, we considered the three different stages of video case study research: preproduction, production and postproduction ${ }^{2}$ (Calvo and Morales, 2017).

The study was conducted in three phases over seven months (from February to September 2017). In the first phase, a literature search was conducted to gain a good understanding of SI and HEIs in Colombia, and in particular the PCIS at Uniminuto University. We investigated the objectives, activities, and developmental trajectory of Uniminuto University, founded by the priest Rafael Garcia Herreros in 1992, and the origins and development of the PCIS. For this, we analysed the content of reports and documentation including book publications, journal articles and grey materials. In the second phase, we conducted 15 in-depth semi-structured video interviews with key stakeholders of the PCIS (see Table 1 for more details). Each face-to-face semi-structured interview, conducted in Spanish, lasted between 30 and 90 minutes and was video-recorded and transcribed verbatim.

The schedule of interviews consisted of two sections: the first involved questions about individual participant features (e.g., gender, age, occupation), and the second consisted of open-ended questions related to the role of the PCIS promoting and supporting SI, and in particular the three SNM processes as indicated in Table 2. In the third phase, fieldnotes were made out of observations done of events and activities organised at the PCIS to complement the data collected.

2 Preproduction includes research design, planning logistical details such as who will be in the video, who will be involved, the equipment used and the initial shooting plan (storyboard and interview schedule).The production stage relates to the data collection. The postproduction stage includes data processing and analysis and putting all the pieces together (Calvo and Morales, 2016). 
Table 1

Data collection from semi-structured interviews

\begin{tabular}{|c|c|c|c|c|}
\hline Interviewees & Role & Gender & $\begin{array}{l}\text { Interview } \\
\text { Duration }\end{array}$ & $\begin{array}{c}\text { Transcription } \\
\text { pages }\end{array}$ \\
\hline 1 & $\begin{array}{l}\text { Vice-Chancellor, Main } \\
\text { Campus }\end{array}$ & Male & 90 & 11 \\
\hline 2 & Manager, PCIS & Male & 60 & 5 \\
\hline 3 & $\begin{array}{l}\text { Director of the appro- } \\
\text { priation of Social } \\
\text { Knowledge }\end{array}$ & Female & 40 & 3 \\
\hline 4 & $\begin{array}{l}\text { Leader of the Social } \\
\text { Innovation School }\end{array}$ & Male & 50 & 4 \\
\hline 5 & $\begin{array}{l}\text { Staff, Observatory of } \\
\text { Social Innovation }\end{array}$ & Male & 55 & 5 \\
\hline 6 & $\begin{array}{l}\text { Leader of Emprendever- } \\
\text { de }\end{array}$ & Male & 40 & 3 \\
\hline 7 & $\begin{array}{l}\text { Director of the Obser- } \\
\text { vatory of Social Innova- } \\
\text { tion }\end{array}$ & Male & 45 & 4 \\
\hline 8 & $\begin{array}{l}\text { Corrdinator of the Pla- } \\
\text { tform of Projects }\end{array}$ & Female & 60 & 5 \\
\hline 9 & $\begin{array}{l}\text { Professor at the peace } \\
\text { degree }\end{array}$ & Male & 30 & 3 \\
\hline 10 & Staff at STEM & Male & 55 & 5 \\
\hline 11 & Staff at Projects & Male & 40 & 3 \\
\hline 12 & $\begin{array}{l}\text { Director of the Platform } \\
\text { of Projects }\end{array}$ & Male & 45 & 4 \\
\hline 13 & Staff, Research & Male & 50 & 5 \\
\hline 14 & $\begin{array}{l}\text { Entrepreneur, Shape- } \\
\text { brand (Emprendeverde) }\end{array}$ & Female & 40 & 3 \\
\hline 15 & $\begin{array}{l}\text { Entrepreneur, Mixtura } \\
\text { (Emprendeverde) }\end{array}$ & Female & 45 & 4 \\
\hline
\end{tabular}


Table 2

Semi-structured interview script

\begin{tabular}{|c|c|c|}
\hline Theory & Concept & Interview questions \\
\hline \multirow[t]{5}{*}{ General questions } & & What is your name, gender and age? \\
\hline & & What is your role at the PCIS? \\
\hline & & How it all started? \\
\hline & & $\begin{array}{l}\text { What has been your role in the } \\
\text { PCIS? }\end{array}$ \\
\hline & & $\begin{array}{l}\text { What are the challenges that the } \\
\text { PCIS is currently facing? }\end{array}$ \\
\hline \multirow[t]{12}{*}{$\begin{array}{l}\text { Strategic Niche } \\
\text { Management }\end{array}$} & $\begin{array}{l}\text { Social network } \\
\text { building }\end{array}$ & $\begin{array}{l}\text { Which partners have been involved } \\
\text { so far? }\end{array}$ \\
\hline & & $\begin{array}{l}\text { How was the interaction between } \\
\text { partners? }\end{array}$ \\
\hline & & $\begin{array}{l}\text { Were there enough resources } \\
\text { available? }\end{array}$ \\
\hline & & Who provided which resources? \\
\hline & & $\begin{array}{l}\text { Did the size of the network increase } \\
\text { or shrink? }\end{array}$ \\
\hline & $\begin{array}{l}\text { Articulation of visions } \\
\text { and expectations }\end{array}$ & $\begin{array}{l}\text { Did an overall shared vision } \\
\text { emerge? }\end{array}$ \\
\hline & & How have the expectations evolved? \\
\hline & & $\begin{array}{l}\text { How have expectations been } \\
\text { articulated between partners? }\end{array}$ \\
\hline & & $\begin{array}{l}\text { On which experiences were the } \\
\text { expectations based? }\end{array}$ \\
\hline & Learning processes & $\begin{array}{l}\text { What type of learning occurred in } \\
\text { the project? }\end{array}$ \\
\hline & & How was learning organised? \\
\hline & & $\begin{array}{l}\text { What were the most surprising } \\
\text { results? }\end{array}$ \\
\hline
\end{tabular}


For data analysis, we used a similar procedure as the one described by Naber et al (2017). First, an open coding strategy was used in order to identify the development of a SI niche within the PCIS. SNM concepts were used as sensitizing concepts to direct the analysis, meaning that raw data was compared with the theoretical background discussed in the theory section, in particular the three main processes that highlights the current developmental stage of the niche: social networks, expectations and visions and learning processes. Key codes were identified from the video interviews, fieldnotes and secondary sources and were refined as the analysis evolved. An iterative analytical process was used to draw out the key codes, commonalities and variations across stakeholders' responses, and analysed according to theoretically-informed codes. Ethical approval was obtained from participants to publish a video and other research related materials, which included informed consent and 'responsible' research practice.A short video was produced using Final Cut Studio 3, a professional video and audio program..$^{3}$

\section{Country Context}

Colombia has traditionally been a country that has looked to the global North for its model of development; one characterised by the support of big corporations and the public sector leaving little space for grassroots innovations. Yet, there has been a recent interest in the support of peer to peer social and solidarity initiatives including grassroots social innovations (Roig, 2014; Montesinos \& Montesinos, 2014; Calvo and Morales, 2015).

Since 2010, the Colombian government, particularly through the Technology, Information and Communications Ministry (in Spanish, Ministerio de Tecnologías de la Información y las Comunicaciones de Colombia or MINTIC), has promoted grassroots SI initiatives by implementing strategic programmes and creating new scenarios through partnerships between the state, for-profit and non-profit organisations. The Social Innovation Centre (in Spanish, Centro de Innovación Social or CIS) within the 'National Agency for Overcoming Extreme Poverty' (in Spanish,Agencia Nacional para la Pobreza Extrema, ANSPE) was also founded in 2011 to support SI initiatives for extreme poverty eradication, aiming to help 1,500,000 families out of extreme poverty by 2020 (Pulford, Hackett \& Daste, 2014; Castillo, 2011; Villa and

3 See video link here: https://www.youtube.com/watch?v=mH8oudlUiZA\&feature=youtu.be 
Melo, 2015; Frias et al., 2013). In 2013, the Social Innovation National Node (in Spanish, Nodo Nacional de Innovación Social or NNIS ${ }^{4}$ ) was also created as a platform for collective action, to enable the construction and implementation of SI policies, programmes and projects by citizens and communities, such as 'the Hilando Project', where they have mapped SI practices in 14 departments across the country in collaboration with several Colombian universities, including Uniminuto University ${ }^{5}$ (ANSPE, 2013; CEPAL, 2009).

The Administrative Department of Science, Technology and Innovation (in Spanish, Departamento Administrativo de Ciencia, Tecnología e Innovación or Colciencias), the Colombian government agency that supports fundamental and applied research in Colombia has also started supporting SI related projects since 2010. Moreover, several universities have started to incorporate the term 'social innovation' within their curriculum and programmes. An example of this is ICESI university in Cali that has also developed a Master's programme on the Management of Social Innovation practices. Yet, Uniminuto University that is part of Corporación Minuto de Dios founded by the Father Rafael Garcia Herreros in 1992, has been considered a SI pioneer within the HE sector in Colombia (Rocha, 2011; Bernal, 2013).

\section{RESEARCH FINDINGS AND DISCUSSION}

We apply SNM to assess 1) the developmental trajectory of a SI niche within the PCIS at Uniminuto University, 2) to identify the phase of niche development the sector appears to be exhibiting by looking at the nichebuilding processes of social network building, articulation of visions and expectations and learning processes, 3) and explore the challenges the SI niche currently has within the current HE system regime.

\subsection{The developmental trajectory of the SI niche}

Table 3 indicates the developmental trajectory of the SI niche within the PCIS at Uniminuto University presenting the evolution from the local to a global phase.

4 NNIS was implemented by the Colombian Government with the Ministry of Information Technology and communications (in Spanish, Ministerio de Tecnologías de la Información y las Comunicaciones (MinTIC), the National Learning Service (in Spanish, Servicio Nacional de Aprendizaje (SENA) and the Department for Social Prosperity (DPS).

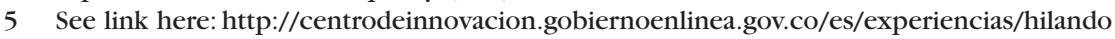


In 1950, Father Rafael García began hosting a radio show called 'El Minuto de Dios' (God's Minute), a daily one-minute show of religious reflection. It proved popular and soon expanded on the radio and moved to television in 1955, making it the longest-running programme on Colombian television until today. In 1961, he commenced the Million Banquet (in Spanish, Banquete del Millón) as a fundraising campaign, where the wealthy paid large amounts to eat a simple meal (Domanski et al., 2016). Rafael used the funds to build houses for the poor. Among other things that the Minuto de Dios Organisation (in Spanish, Organización Minuto de Dios or OMD) has established are: the contemporary art museum (created in 1966), Minuto de Dios Charismatic Centre Corporation (created in 1976), Ateneo Juan Eudes School (created in 1979), Lumen 2000 TV and Minuto de Dios Radio (created in 1985), Fundases (created in 1988), Uniminuto University (created in 1992), and Coop-Uniminuto (created in 2001) (Gnecco de Ruíz, 2014).

Table 3

The evolution of the SI niche from a local to a global phase

\begin{tabular}{|c|c|c|}
\hline Phase & Period & Description \\
\hline $\begin{array}{l}\text { 1- Local phase (a set } \\
\text { of isolated projects) }\end{array}$ & 1992-2012 & $\begin{array}{l}\text { - The establishment of UNIMINUTO } \\
\text { university aiming to provide HE for } \\
\text { disadvantaged people. }\end{array}$ \\
\hline $\begin{array}{l}\text { 2- Inter-local phase (a } \\
\text { niche level emerges } \\
\text { where projects } \\
\text { share knowledge } \\
\text { and experiences) }\end{array}$ & $2012-2014$ & $\begin{array}{l}\text { - The establishment of the PCIS in } 2012 \\
\text { to gather all the different SI related } \\
\text { projects at Uniminuto University. }\end{array}$ \\
\hline $\begin{array}{l}\text { 3- Trans-local phase } \\
\text { (actors play a role } \\
\text { in developing } \\
\text { interest to manage } \\
\text { external } \\
\text { expectations and } \\
\text { local knowledge is } \\
\text { systematically fed } \\
\text { up to aggregate } \\
\text { learning required at } \\
\text { niche level) }\end{array}$ & 2014-2016 & $\begin{array}{l}\text { - The PCIS expanded the projects at a } \\
\text { national level, particularly developed } \\
\text { several activities in the Cundinamarca } \\
\text { region. } \\
\text { - The PCIS workedin } 5 \text { areas:Appropriation } \\
\text { of Social Knowledge, Platform Projects, } \\
\text { Observatory of Social Innovation, } \\
\text { Knowledge Network and Research } \\
\text { Support Platform. }\end{array}$ \\
\hline
\end{tabular}




\begin{tabular}{lll}
\hline \multicolumn{1}{c}{ Phase } & \multicolumn{1}{c}{ Period } & \multicolumn{1}{c}{ Description } \\
\hline $\begin{array}{l}\text { 4- Global phase } \\
\begin{array}{l}\text { (greater } \\
\text { institutionalisation } \\
\text { and standardisation } \\
\text { of practices in the } \\
\text { field with niche } \\
\text { standards shaping } \\
\text { local practices, } \\
\text { therefore becoming } \\
\text { a stable regime) }\end{array}\end{array}$ & $\begin{array}{l}\text { - Since 2016, the PCIS has moved at an } \\
\text { international level working in } \\
\text { collaboration with other partners } \\
\text { across the globe (e.g. Japan, EEUU, } \\
\text { Spain). }\end{array}$ \\
\hline
\end{tabular}

Uniminuto University (in Spanish, Corporación Universitaria Minuto de Dios), was established with the aim of providing affordable education for low-income and vulnerable people across the country, including rural areas where higher education is non-existent (Velez, 2013). Since its foundation, Uniminuto University, currently with more than 120,000 students in 18 departments across the country, has created a wide range of sustainable solutions to poverty and disadvantage. Uniminuto has so far supported 2,000 displaced in their entrepreneurial ideas and has advised to more than 1,500 small companies to increase their productivity. The core of what Uniminuto University does has not changed over the last years, increasing the number of SI related projects, and later unifying with the creation of the PCIS in 2012 with the support of Colciencias (Arias, 2013b). The PCIS defines SI as a new way to solve the problems and needs of communities (Arias, 2013b). This can be a product, service or practice or a management model that is: 1) more effective than a solution that is currently used in the community; 2 ) generated in a participative way between the community and the researchers; 3) sustainable and scalable; and 4) able to generate permanent changes in the society (Domanski et al., 2016). The PCIS works around three main activities (research, teaching and social impact) and it has five areas of work: Appropriation of Social Knowledge (in Spanish,Apropiación Social del Conocimiento); Platform Projects (in Spanish, Plataforma de Proyectos); Observatory of Social Innovation (in Spanish, Observatorio de Innovación Social); Knowledge Network (in Spanish, Red de Conocimiento); and Research Support Platform (in Spanish, Plataforma de Apoyo a la Investigación). 
While the objective of the PCIS for the first two years was to create a framework for the establishment of the organisation, in 2014-2015 the aim was to consolidate SI related projects created at a national scale. The PCIS has been principally financially supported during the first four years by Uniminuto University and the Cundinamarca government (in Spanish, Gobernación de Cundinamarca), where they have worked on several projects to promote SI, supporting more than 300,000 people in the region. ${ }^{6}$ The PCIS currently has 45 staff and it counts with around $\$ 500,000$ of annual budget plus other income received from the public and private institutions. Since 2016, the target plan has been to move to an international level, aiming to become the educational leaders on SI working with partners across the globe including universities and consultancy companies in the United States, Japan and Spain among others. The three topics that the PCIS is working on at present are:a) environment and agroecology, b) technology, education and culture and c) peace, conflict and social dynamics. In relation to environment and agroecology, the PCIS has created initiatives such as 'Emprendeverde', an incubator to support environmentally-related SI businesses across the country. Regarding technology, education and culture, a good example of an initiative is the 'STEM Project' that introduces students in local schools to the world of robotics to give them hands-on experiences of science and engineering. Finally, in relation to peace, conflict and social dynamics, several initiatives have taken place such as the 'Arts and Music Project for the Peace' that was conducted in Tolima in 2016.

\subsection{Evaluating the SNM processes for the development of the SI niche}

The table below gives a brief overview of how interview segments were coded based on our interpretation of the qualitative data and taking into account the three SNM processes to evaluate the development of a SI niche: social network building, the articulation of visions and expectations and learning processes.

6 Cundinamarca is one of the thirty-two departments that are part of the Republic of Colombia with Bogota as its capital city. 
Table 4

Indicators and values of the theoretical model

\begin{tabular}{lll}
\hline \multicolumn{1}{c}{ Process } & Created code & Examples of interview (transcript) segment \\
\hline $\begin{array}{l}\text { 1. Social } \\
\text { network } \\
\text { building }\end{array}$ & National & We have links with national government, for \\
& & $\begin{array}{l}\text { example, with the MINTIC, local government } \\
\text { departments, private companies and third sector } \\
\text { organisations (e.g., Siemens Foundation, and } \\
\text { universities including Javeriana and Andes } \\
\end{array}$ \\
& (Interviewee 5). \\
& We have contracts with foundations, for example, \\
& with Davivienda Foundation, Proyecto Civico, \\
& Ciudad Bolivar Foundation and other private \\
& companies (Interviewee 8).
\end{tabular}

International For example, the STEM project... well, we networks brought this model from a university in the United States, the Robomatter-Carnegie Mellon University, to help students in local schools to improve their level in mathematics and other related science subjects. We've applied it in eight schools in Cundinamarca and now it has been expanded to other locations due to the success of the project! This has been indeed one of the most significant achievements! (Interviewee 10).

Formal and We meet regularly to make sure we are all informal internal informed of the progress done and that everybody knows what is happening. Well, we have also networks. created a space online to communicate with leaders in different parts of the country to make sure communication is great (Interviewee 8).

We organise formal and social meetings to keep us updated. There is a good environment in the workplace; people meet to exchange ideas about their projects as well as socialise for lunch. It is like a family! (Interviewee 3). 


\begin{tabular}{lll}
\hline \multicolumn{1}{c}{ Process } & Created code & \multicolumn{1}{c}{ Examples of interview (transcript) segment } \\
\hline $\begin{array}{l}\text { 2.Articulation } \\
\text { of visions } \\
\text { and expec- } \\
\text { tations }\end{array}$ & $\begin{array}{l}\text { Shared vision } \\
\text { and values at } \\
\text { Uniminuto } \\
\text { university. }\end{array}$ & $\begin{array}{l}\text { The spirit of the PCIS is in its foundation; is in } \\
\text { its DNA. Since Uniminuto started with the work } \\
\text { done by Father Rafael Garcia Herreros, it is an } \\
\text { innovative university that focused on helping } \\
\text { the community (Interviewee 2). }\end{array}$ \\
& $\begin{array}{l}\text { This is a university that changes the lives of } \\
\text { people. We have been recognised by the local } \\
\text { community and they trust us, well... they know } \\
\text { we are here to support them in their development } \\
\text { (Interviewee 7). }\end{array}$
\end{tabular}

Inspiring Emprendeverde, our business incubator others and programme, supports entrepreneurs that are propagating a working with environment related activities. shared vision One of the things we do is to buy products from them; for example, we buy food and drinks from Mixtura, a company we are currently working with.Another example is Shapebrand, a company that creates trophies. We support the founder by buying these trophies for the university. By doing this, we give them financial stability (Interviewee 6).

As this university has around 127,000 students in 84 locations across the country, we have introduced them to SI throughout our courses. Well... they [students] have to do practices related to social responsibility and innovation. Some of our students have identified problems in their local areas and have looked for innovative solutions; they have started their own projects to help the local community. It is fantastic to see how our values and vision are affecting other people positively, and how the students have become promoters of innovative initiatives to help their communities (Interviewee 4). 


\begin{tabular}{cll}
\hline Process & Created code & \multicolumn{1}{c}{ Examples of interview (transcript) segment } \\
\hline $\begin{array}{l}\text { 3. Learning } \\
\text { processes }\end{array}$ & $\begin{array}{l}\text { Working with } \\
\text { other } \\
\text { organisations: } \\
\text { a key for } \\
\text { learning } \\
\text { experiences }\end{array}$ & $\begin{array}{l}\text { We've developed a map of } 107 \text { SI related } \\
\text { organisations in the country to learn about the } \\
\text { problems they work with and share ideas } \\
\text { (Interviewee 5). }\end{array}$ \\
& $\begin{array}{l}\text { We've worked with social innovators and } \\
\text { universities that are working on projects related } \\
\text { to social innovation developing a wide range of } \\
\text { projects. For example, we've developed a project } \\
\text { with the University of Andes and Rosario } \\
\text { University to support SI practices in } \\
\text { Cundinamarca (Interviewee 9). }\end{array}$
\end{tabular}

Contribution I have personally learned a lot from the staff at the to other niches PCIS, and in particular Emprendeverde, how to manage my business and scale up (Interviewee 15).

Camilo and the staff at Emprendeverde have supported me immensely by giving me not only advice for my business, but also providing me with key contacts for the business. I have learned a lot; it is difficult to say in words the contribution they have given to my company (Interviewee 14).

Learning by We have learned a lot by reflecting on our doing experiences. For example, we have changed the way we were doing things in here... (Interviewee 12).

We work with the community to ensure that it suits the location where we develop these projects. We give relevance to the knowledge and experience of peasants, trying to recuperate their local knowledge, for example, traditions such as gathering in the kitchen to socialise with the family. We've realised how collective knowledge can change things! (Interviewee 11). 


\subsubsection{Social Network Building}

Growing niches depend on expansion of networks and network building activities, both internally (building a sense of community to encourage information-sharing) and externally (to attract resources and influence). The findings suggest that the building of a social network was in particular important for growth. There is good evidence that the PCIS engage in networking activities in a variety of ways, with a diverse set of national and international partners, to share information and experiences as well as work in collaboration for the development of SI projects. When asked to name important partners, respondents most frequently named national and local government departments, foundations, private companies and other universities. See examples of interview transcripts in Table 4.

Some respondents commented on their work with actors who have resources and how they have tried to change their agendas and visions by doing it. They pointed out their ability to attract funds from different institutions, the main one being Colciencias and the Cundinamarca local government:

We have been funded primarily by the Uniminuto University with the support of Colciencias. After that, the Cundinamarca government gave us substantial money for the last four years to promote and support social innovation in the area.This has been a fantastic opportunity to develop projects in the region and promote the PCIS, but obviously, this has focused our energy in developing social innovation projects in that particular region, which was not the initial idea! (Interviewee 2).

There was also evidence of the creation of networks with organisations at an international level. Some of the international partners that the PCIS has worked with since its establishment are: IDEO, Strive Together, Robomatter-Carnegie Mellon University and Colorado School of Mines in the USA; Pontificia Universidade Católica do Rio Grande do Sol in Brazil; LaFis and Fundación para la Innovación Social in Chile; University of Dortmund in Germany; University of Tokyo in Japan; the National Agency of Information (NIA) in the Republic of Korea; and ICA2, Parque Científico de Madrid, Universidad Politécnica de Valencia, Parque Científico de Leganés, Distrito 22@ and Innobasque in Spain.An example of this strong relationship with international partners is shown in Table 4 where one of the respondents highlighted the relevant activity done with a university based in the United States to develop an educational project for disadvantaged children. 
Moreover, we found evidence of considerable formal and informal internal networking within the niche. Respondents mentioned that much of the effort of networking within the members has been done by organising regular meetings and talks with leaders of the different projects to ensure the work was done in a similar line (see Table 4 for details of transcript segments). Hence, we find that social network is a vital aspect of the development of the PCIS, and that while there is good evidence of contributions to global-level networking, as predicted by SNM in the formation phases of niche-development, there is more activity and reliance on pre-existing networks within the project and at a national level (Witkamp et al., 2011). This indicates that the sector is currently at the 'trans-local' phase of niche development, moving towards the global-level phase, and it is still at an early stage for transforming the current system regime (Geels and Deuten, 2006).

\subsubsection{Articulation of visions and expectations}

As the development of shared expectations and visions is considered crucial for robust niche development, we looked for evidence of such visions within the case study selected.The findings demonstrate that all the respondents from the PCIS had a common understanding of the term 'social innovation' referring to it in relation to community, claiming: 'social innovation is a solution to problems that the community has primarily done in a participative way', 'an instrument to impact on the community', 'solutions for the community that can be replicated and scalable'. This is in line with the definition used by Zapf (1989) that considers SI as new social practices that better solve existing challenges in the community.

As several respondents highlighted one of the key elements of being successful has been the support they have from Uniminuto university, as SI is at the core of their mission:

We are proud we have sustained our park. Well, if we compare with other SI parks that we've seen, in few years' time they disappear, we are still here; the idea is to sustain and make it strong. We have to accept that we would not be here without the support of the university and the people who are at the top; they are the ones that want to see this park growing and becoming a leading world example of SI and education (Interviewee 1).

The findings also indicate that participants from the PCIS had very clear visions and well-defined aims of their goals and objectives, as they had 
kept to the original vision of the university, and have maintained it over time. Table 4 brings examples of interview transcript segments. Interestingly, another aspect that emerged from the interviews was that the PCIS has been extremely effective in attracting members that have not only the professional skills but also a shared vision required to develop their projects:

We have a great team and this has been crucial for the success of the park. We have been able to develop things through our collective knowledge and similar interest and visions! (Interviewee 7).

We have a great team of people from different disciplines but with similar values, well... the environment is great. It is a pleasure to work here; people value the creativity of everyone and support each other! (Interviewee 8).

Respondents reported enthusiastically of the plans they have to continue with the promotion of SI activities within the PCIS. As pointed out by one of the leaders of the PCIS: 'We want to evangelise social innovation to make sure people move towards the sector' (Interviewee 1). Yet, and although the PCIS has been recognised by the International Association of Science Parks (IASP) as the first Scientific Park for SI in the world, a number of respondents expressed the view that more dissemination was needed to improve the perception of the PCIS at a national and international level:

Something that is missing is to put our experiences in scientific data, such as academic papers, to help us disseminate our experiences and look for external partners at national and international levels. We have a lot of experience, but we lack dissemination (Interviewee 12).

Another important aspect that emerged from the findings is how the PCIS has been involved in setting up new projects, inspiring others and propagating a shared vision (see Table 4 with examples of interview transcripts). Thus, the evidence indicates that respondents were aiming to achieve wider societal changes and that there is an influential niche able to shape the development of future projects within its overall shared vision. The PCIS, as illustrated in Figure 1, currently exhibits characteristics of the 'trans-local' phase regarding shared visions and project expectations, where the local knowledge has been fed forward to constitute the aggregated learning required at niche level (Geels and Deuten, 2006). 


\subsubsection{Learning processes}

Sharing learning is an important activity for our case study, indicating that the types of learning, and the people with whom it is shared, vary over time and according to different phases of the development of the sector. The PCIS showed evidence of learning being shared 'upwards' with intermediary organisations developing projects. The most prominent mechanisms for sharing learning were: working with external consultants to produce learning materials and engaging with intermediaries to develop projects. As an example of this, one of the respondents highlighted the recent book publication they have produced in collaboration with other scholars and experts on SI and education in Latin America:

\footnotetext{
We rely on a network of experts in different Latin American countries that meet regularly to share experiences and ideas. Out of this, for example, we have recently published a book entitled 'Innovación Social en Latin America' to promote social innovation in the region (Interviewee 1).
}

Moreover, most respondents acknowledge working with organisations that are part of the sector as being relevant for their learning experiences (see table 4 with examples of interview transcripts). Interestingly, some of the learning has contributed not necessarily to the niche (SI in higher education), but rather to supporting another niche, which is an important contribution to the SNM theory, suggesting that learning happens on a single niche-regime interaction:

We've worked even with private companies; an example of this is the work we have done with Osensa, an oil company, encouraging them to develop SI related projects! (Interviewee 12).

A couple of entrepreneurs that had been supported by the PCIS corroborated the contribution of the PCIS to other niches (see examples of interview transcripts in Table 4). Moreover, respondents accepted that they were also actively engaged in formal evaluation or monitoring processes, whereby learning was consolidated and passed to intermediaries. Another mechanism of learning-sharing reported was through information sharing (meaning informal, ad hoc contact by telephone, emails or at events) to acquire information and advice and through hosting visits to the projects.

Within the PCIS, we've developed a website and a section called SocioInnova to share all their publications. It is available for everyone! (Interviewee 13). 
Once, there was a university that approached us saying they wanted to collaborate with the PCIS by organising an international event on the topic of SI.They were surprised when we gave them our contacts; they could not believe it! I think if we want to be part of the SI movement, we need to share! (Interviewee 1).

One of the processes of learning with other individuals and organisations was reported to be mentoring. As one of the participants stated:

The Park promotes different projects from people, for example, a peasant that created a machine to solve a problem he had with his production. We supported him by giving advice and we have learned a lot from him as well. He is currently studying a degree at this university (Interviewee 8).

We also found that learning plays an important role within groups in developing, improving and evolving these initiatives (Schot and Geels, 2008). The most prevalent means through which this occurred was 'learning by doing', which took the form of, for instance, adapting their activities to suit local contexts and conditions better (see Table 4 for more details). In addition to this, there was apparent agreement among respondents about the importance of having different locations across the country to make an impact and influence others:

The fact that we are working in different regions in the country helps us to disseminate the work and promote social innovation, making a bigger impact. For example, we have a competition called 'Ligas del Conocimiento' where we give the opportunity to students at Uniminuto University in different parts of the country (e.g., the Amazon region) to participate with their social innovation business idea to solve a problem in their community. They pitch their idea and if they win the competition, we give them money to start-up (Interviewee 13).

The evidence indicates that learning has taken place within the PCIS, some being 'pulled out' by intermediaries and others 'pushed out' by projects themselves through formal evaluations, monitoring and structured, codified learning mechanisms. In terms of what types of learning is shared, the findings indicate that socio-cultural, human and organisational aspects were the most commonly shared, being less popular the financial aspects. Therefore, these findings suggest that the PCIS is displaying characteristics typical of the third stage of niche development (trans-local phase), where niche-level actors are playing a significant role in the process of aggregating shared learning within the projects themselves, which 
is very significant to the project's development and progress as well as sharing learning with other organisations (Geels and Deuten, 2006).

\subsection{The challenges of scaling up: from the trans-local to the global phase}

In testing how useful SNM is for explaining developments at the PCIS, our analysis reveals that there is indeed evidence of an emerging niche of the type described in SNM. In terms of the phases of niche development, indicated in Figure 1, the PCIS appears to be performing some of the roles typical of the trans-local phase, enabling wider SI diffusion by aggregating project learning and sharing resources with new projects. Yet, our analysis indicates some possible routes for the development of the niche moving from the trans-local to the global phase with a number of challenges to overcome in so doing. Results from the analysis indicate that there are factors preventing the niche from scaling up from the trans-local to the global phase. One of the main challenges is related to leadership and management issues within the organisation. As some of the respondents claimed:

One of the biggest problems is the relationship between the park and the university, as the academic time is different, and both operate at different rhythms, mainly in the administrative part. Well, the university follows the academic calendar and it has a break at a particular time of the year, but the park doesn't stop, so it can make things complex at times mainly for the admin people (Interviewee 5).

Some of the challenges we have experienced has been that although we are part of the university, we have a different rhythm, mainly for admin people. Well, the lack of trust, for example, from the admin team at university that some of the entrepreneurs, particularly the young ones, will not be able to deliver things on time. They, both staff at university and the PCIS including entrepreneurs, have been able to manage and adjust perfectly, which is great! (Interviewee 8).

A further point of discussion relates to the financial sustainability of the park. As one of the respondents stated:

The PCIS has difficulties becoming financially sustainable. We have achieved social stability working in collaboration with communities, and we are missing the financial aspect now (Interviewee 12).

Additionally, respondents reported difficulties for people when explaining outside the PCIS what SI is and why it is important. This was perceived as a barrier to promote the sector within the university: 
Not everyone understands the meaning of social innovation within the university. Sometimes people from university are not open to new concepts. Well, we have, as I like to call it, organised chaos! (Interviewee 1).

The findings demonstrate that although there was a preference among universities to work around the mainstream HE system regime because of the pressure created from the Colombian government, this was gradually changing. As one of the respondents clearly stated:

There is a lot of pressure for academics to work with large corporations to contribute to innovation related issues around technology. This university (Uniminuto) is doing something different, bringing innovative solutions to disadvantaged groups and empowering the community by using a participatory approach. We put efforts to support and promote grassroots social innovations. Well, ... the public sector has been supporting the work of universities in relation to technology and innovation with private large multinational companies for many years, but there has been a light change recently, and we can see some new initiatives that the government is supporting such as the Hilando Program we have been involved with to map SI projects across the country (Interviewee 2).

The findings indicate that despite the fact that the PCIS at Uniminuto University has shown a great achievement by all the work developed and the government is also showing more interest to the SI field, it presents current limitations to move to the global-phase level, where the niche leads to a radical HE regime transformation (see Figure 3). To become a more robust niche, we consider there to be a need to increase the capacity use niche experience of the PCIS at Uniminuto University to influence perceptions of regime actors to actively create cracks in the regime.

\section{CONCLUSIONS}

In this paper, we have applied SNM to test the usefulness of the theory at explaining the phenomena of the role of universities contributing to the development of SI niches. We have examined this by using the PCIS at Uniminuto University in Colombia as a case study to establish to what extent it is displaying characteristics of a niche and the potential it has to diffuse and influence the current HE system regime (Raven, 2005; Grin et al., 2010; Hargreaves et al., 2013).

The following conclusions can be drawn from this study. First, the paper has demonstrated that an emerging SI niche is evident, and it is at the translocal phase (Geels and Deuten, 2006). Second, the paper has provided evidence of the different elements that are occurring within the PCIS: social 
networking, expectations and visions and learning processes (Schot and Geels, 2008). The findings indicate that the PCIS had very clear visions and well-defined expectations of their goals and objectives, inspiring other individuals and organisations. Moreover, evidence reveals that sharing learning is important for our case study within and outside the PCIS, as well as social networking where there is more activity and reliance on pre-existing networks within the project and at a national level. Yet, they are currently increasing their network activities at an international level.

Third, the paper has shown that there are current limitations within the PCIS to develop the SI niche moving from the trans-local to the global phase. The findings suggest that at present, the PCIS is struggling with organisational management and financial sustainability as well as the current existing tensions between the regime and the niche (Geels, 2002). This raises questions about whether this emerging sector will ever coalesce into a robust niche, and where support is most needed to strengthen the sector to influence the system regime. This is particularly relevant within our case study, as the objective is not to completely displace the incumbent regime but to build a form of parallel infrastructure that aims to provide necessary systems that individuals cannot provide themselves. Yet, we can see that the current demand within HEIs in Colombia is to have a more flexible and open approach to education where the work done with grassroots organisations and communities is considered relevant and appreciated not only the one done with large multinational companies and public sector institutions.

To conclude, we recognise both the limitations in our research and the scope for further enquiry. Although the PCIS represents an interesting case study to understand the role of HEIs in contributing to the development of a SI niche, we cannot claim generalisability, as it looked at a particular phenomenon in a particular location, making it difficult to generalise to other situations. Building on the current work, it would be appropriate to look at different universities in the country to examine the extent to which they are contributing to SI and how they can influence the current mainstream HE system regime. Likewise, how other Latin American universities are working at promoting and supporting SI practices would be interesting to explore further. Conducting a comparative study between universities in emerged and emerging economies to look at their differences in terms of resources and infrastructure would also be good. 
Acknowledgements

This work was carried out with funding from the Newton Fund. The study would not have been possible to conduct without the generous assistance of staff from the PCIS at Uniminuto University. The authors would like to thank the three anonymous reviewers for their helpful comments.

\section{REFERENCES}

Agencia Nacional para la Superación de la Pobreza Extrema (ANSPE) (2013). Catálogo de iniciativas 2012 [en linea]. Retrieved from: http:// www.innovacionsocialcolombia.com/hilando/ [Consulted 5 August 2018].

Arias, Jefferson (2013b). Parque Científico de Innovación Social. Trabajo presentado en el II Foro de emprendimiento, Innovación y competitividad, Ciudad de Panamá, Panamá.

Avelino, Flor and Kunze, Iris (2009). Exploring the transition potential of the ecovillage movement, in Paper Presented at the KSI European Conference on Sustainability Transitions, 4-5 June 2009, Amsterdam.

Benneworth, Paul and Cunha, Jorge (2015). Universities 'contributions to social innovation: reflections in theory and practice, European Journal of Innovation Management, Vol 18, N4, pp.508-527.

Benson, Lee; Harkavy, Ira and Puckett, John (2007). Dewey's Dream: Universities and Democracies in an Age of Education Reform. Temple University Press:The University of Michigan.

Berkout, Frans (2002). Technological regimes, path dependency and the environment, Global environmental change, 12(1):1-4.

Bernal, Camilo (2013). Una bistoria de fe y razón. En UNIMINUTO (Ed) UNIMINUTO: educacion integral al alcance de todos (pp. 44-65). Bogota: Corporacion Universitaria Minuto de Dios -UNIMINUTO.

Boni. Alejandra; Walker, Melanie (2009). Universities and Global Human Development Theoretical and empirical insights for social change. Routledge, London:Taylor \& Francis.

British Council (2016). Social enterprise in a global context, The role of higher education institutions, London: British Council.

Brundenius, Claes; Göransson, Bo; Carvalho de Mello, Jose Manuel (2017). Universities, Inclusive Development and Social Innovation. An international perspective, Springer: International Publishing AG. 
Cajaiba-Santana, Giovany (2014). Social innovation: Moving the field forward. A conceptual framework, Technological Forecasting \& Social Change, 82 (2014) 42-51.

Calvo, Sara (2015). Connecting Social Enterprise and Higher Education: Universities as drivers in the support of Social Enterprises in the United Kingdom; in Carvalho, L, Handbook Research on Entrepreneurial Success and its Impact on Regional Development, IGI Global.

Calvo, Sara; Morales, Andrés (2016). Conducting Video Research in the Social and Solidarity Economy: Empowering the Cinderella Economy Towards Social Justice, International Journal of E-Politics, 7(4), 1-16.

Calvo, Sara; Morales, Andrés (2017). The Social and Solidarity Economy: The world's economy with a social face. Routledge: London.

Castillo, Darío (2011). Políticas Públicas y cooperativismo en Colombia, 30 años de encuentros y desencuentros. Bogotá: IEMP Ediciones.

Checkoway, Barry (2001). Renewing the Civic Mission of the American Research University, The Journal of Higher Education, 72(2): 125-147.

CEPAL (2009). Concurso de experiencias en innovación social 20042009.

Retrieved from: http://www.cepal.org/dds/innovacionsocial/e/concurso. htm [Consulted 5 August 2018].

Deiaco, Enrico; Holmén, Magnus and McKelvey, Maureen (2012). Universities as strategic actors in the knowledge economy, Cambridge Journal of Economics, 36, p.525-541.

Domanski, Dmitri; Monge, Nicolás; Quitiaquez, Germán; Rocha, Daniel (2016). Innovación Social en Latino America. Centro Editorial UNIMINUTO.

Drèze, Jean \& Sen,Amartya (2002). India: Development and Participation, Oxford University Press.

Feller, Irwin; Pailer, Catherine and Roessner, David (2002). Impacts of research universities on technological innovation in industry: evidence from engineering research centers, Research Policy, 31(3), 457-474.

Frias, Nazly; Lozano, Marcela \& Aparicio, Santiago (2013). Barriers and incentives for social innovation in Colombia:Towards the construction of a public policy in this fields. Conference, London, UK.

Gnecco de Ruíz, María Teresa (2014). Innovaciones sociales para la equidad y la inclusion social: el caso de El Minuto de Dios, Bogota. Corporacion Universitaria Minuto de Dips-UNIMINUTO. 
Geels, Frank (2002). Technological transitions as evolutionary reconfiguration processes: a multi-level perspective and a case study, Research Policy, 31, 1257-1274.

Geels, Frank and Schot, Johan (2007). Typology of socio-technical transitions pathways, Research Policy, 36:339-417.

Grin, John; Rotmans, Jan and Schot, Johan (2010). Transitions to sustainable development: new directions in the study of long term transformative change. Routledge Studies in Sustainable Transitions, Taylor and Francis group, London, UK.

Hargreaves, Tom; Longhurst, Noel and Seyfang, Gill (2013). Up, down, round and round: connecting regimes and practices in innovations for sustainability, Environment and Planning, 45, p.402-420.

Hielscher, Sabine; Seyfang, Gill and Smith, Adrian (2013). Grassroots innovations for sustainable energy: exploring niche development processes among community energy initiatives: In Brown, H; Cohen, M; Vergrargt, $\mathrm{P}$ (Eds), Innovations in Sustainable Consumption: New Economics, Socio-technical Transitions, and Social Practices, Edward Elgar, Cheltenham.

Howaldt, Jürgen; Kopp, Ralf (2012). Shaping Social Innovation by Social Research. In: Franz, H.W., Hochgerner, J., Howaldt, J. (Eds.), Challenge Social Innovation. Potentials for Business, Social Entrepreneurship, Welfare and Civil Society, 2012 (pp. 43-55). Berlin, New York: Springer.

Innerarity, Danniel (2010), Otra ciencia económica, Recerca: Revista de pensament $i$ anàlisi, 53-60.

Jewitt, Carey (2012). An Introduction to Using Video for Research Institute of Education, London. National Centre for Research Method. UK: Economic Social Research Council. Retrieved from http://eprints.ncrm. ac.uk/2259/4/ NCRM_workingpaper_0312.pdf

Kemp, René; Schot, Johan; Hoogma, Remco (1998). Regime shifts to sustainability through processes of niche formation: the approach of strategic niche management, Technology Analysis and Strategic Management, 10, p.175-195.

Matheson, Kim (2008). How Universities Can Enable Social Innovation. Open Source Business Resource, Retrieved from http://timreview. ca/article/188 [Consulted 5 August 2018].

McKelvey, Maureen and Zaring, Olof (2017). Co-delivery of social innovations: exploring the university's role in academic engagement with society, Industry and Innovation, 25(6): 63-77. 
Middleton, Chris (2000). Models of State and Market in the modernization of higher education, British Journal of Sociology of Education, 21, 537554.

Montesinos, Abad \& Montesinos, Abad (2014). La economía social y solidaria como alternativa económica. Bienes comunes y democracia, $R e$ cerca: Revista de Pensament y Anàlisi.

Moulaert, Frank., Martinelli, Flavia., Gonzalez, Sara and Swyngedouw, Erik (2007). 'Introduction: Social Innovation and Governance in European Cities. Urban development between path-dependency and radical innovation', European Urban and Regional Studies 14:3, 195-209.

Naber, Rolf; Raven, Rob; Kouw, Matthijs and Dassen, Ton (2017). Scaling up sustainable energy innovations, Energy Policy, 110:342-354.

Nill, Jan and Kemp, Rene (2009). Evolutionary approaches for sustainable innovation policies, Research Policy, 38:668-680.

Perkmann, Markus; Tartari, Valentina; McKelvey, Maureen; Autio, Erkko; Broström,Anders; D’Este, Pablo and Fini, Riccardo (2013).Academic Engagement and Commercialisation: A review of the literature on UniversityIndustry Relations, Research Policy, 42(2): pp.423-442.

Pol, Eduardo and Ville, Simon (2009). Social innovation: Buzz word or enduring term? The Journal of Socio-Economics, 38(6): 878-885.

Pulford, Louise; Hackett, Tricia \& Daste, Diana (2014). A reflection on Strengthening Social Innovation in Colombia. The Young Foundation. Retrieved from: http://youngfoundation.org/wp-content/ uploads/2014/02/Six-Colombia-Report_Screen.pdf, [Consulted 6 August 2018].

Raven, Robert (2005). Strategic Niche Management for Biomass. Eindhoven University Press. Eindhoven.

Raki , Tijana., \& Chambers, Donna (2011). An Introduction to Visual Research Methods in Tourism, Contemporary Geographies of Leisure, Tourism and Mobility. London: Routledge.

Rocha, Diana (2011). Centro -Parque Cientifico de Innovacion Social Minuto de Dios, Bogota: Corporacion Universitaria Minuto de Dios UNIMINUTO.

Roig, Vicente Ordoñez (2014). Economía, valores y democracia. Diálogo con Christian Felber, Recerca: Revista de Pensament y Anàlisi, 153161.

Salter, Ammon and Martin, Ben (2001). The economic benefits of publicly funded basic research: a critical review, Research Policy, 30:509-532. 
Schmitt, Julia (2014). Social Innovation for Business Success, London: Springer.

Schot, Johan and Geels, Frank (2014). Strategic niche management and sustainable innovation journeys: theory, findings, research agenda and policy, Technology Analysis and Strategic Management, 20(5): 537-554.

Schot, Johan and Geels, Frank (2008). Strategic Niche Management and sustainable innovation journeys; theory, findings, research agenda, and policy. Technology Analysis \& Strategic Management, 20(5): 537-554.

Seyfang, Gill and Longhurst, Noel (2013b). Growing green money? Mapping community currencies for sustainable development. Ecological Economics, 86, p. 65-77.

Seyfang, Gill (2009). The New Economics of Sustainable Consumption: Seeds of Change. Palgrave Macmillan, New York.

Seyfang, Gill; Hielscher, Sabine; Hargreaves, Tom; Martiskainen, Mari and Smith, Adrian (2014). A grassroots sustainable energy niches? Reflections on community energy in the UK, Environmental Innovation and Societal Transitions, 13, p.21-44.

Seyfang, Gill and Smith, Adrian (2007). Grassroots innovations for sustainable development: towards a new research and policy agenda, Environmental Politics, 16(4), 584-603.

Smith,Adrian (2006). Green niches in sustainable development: the case of organic food in the United Kingdom, Environment and Planning $C$ : Government and Policy, Vol 24, p.439-458.

Smith, Adrian; Fressoli, Mariano and Thomas, Harry (2013). Grassroots innovation movements: challenges and contributions, Journal of Cleaner Production, 63, 114-124.

Smith,Adrian and Raven, Rob (2012). What is protective space? Reconsidering niches in transitions tot sustainability, Research Policy, 41: 10251036.

Stier, Jill \& Börjesson, Mikael (2010). The internationalised university as discourse: Institutional selfpresentations, rhetoric and benchmarking in a global market, International Studies in Sociology of Education, 20(4), 335-353.

The Young Foundation (2006). Social Silicon Valleys a Manifesto for Social Innovation: What it is, why it matters, how it can be accelerated. Retrieved from: https://youngfoundation.org/wp-content/ uploads/2013/04/Social-Silicon-Valleys-March-2006.pdf [Consulted 8 August 2018]. 
Velez, Santiago (2013). Educación y regionalización para la construcción de una nueva Colombia. En Uniminuto (Ed). Uniminuto Educacion.

Veugelers, Reinhilde and Del Rey, Elena (2014). The contribution of universities to innovation, (regional) growth and employment, EENEE Analytical Report No. 18, Prepared for the European Commission.

Villa, L \& Melo, J (2015). Panorama actual de la innovación social en Colombia. Banco Interamericano de Desarrollo. Retrieved from: https://publications.iadb.org/handle/11319/6957 [Consulted 10 August 2018].

Witkamp, Geert-Jam; Raven, Robert and Royakkers, Lambér (2011). Strategic Niche Management of Social Innovation: the case of social entrepreneurship in the Netherlands, Working Paper 10, Eindhoven Centre for Innovation Studies, the Netherlands.

Yin, Robert (2009). Case Study Research: Design and Methods, Applied Social Research Methods Series. London: Sage.

Zapf, Wolfgang (1989). Über soziale Innovationen, in Soziale Welt, 40 (1-2): 170-183. 
